\title{
Erratum to: Development of doubled haploids from an elite indica rice hybrid (BS6444G) using anther culture
}

\author{
Nupur Naik ${ }^{1}$ Prachitara Rout ${ }^{1}$ Ngangkham Umakanta ${ }^{1} \cdot$ Ram Lakhan Verma $^{1}$. \\ Jawahar Lal Katara ${ }^{1} \cdot$ Khirod Kumar Sahoo $^{2}$. Onkar Nath Singh ${ }^{1}$. \\ Sanghamitra Samantaray ${ }^{1}$
}

Published online: 9 February 2017

(C) Springer Science+Business Media Dordrecht 2017

\section{Erratum to: Plant Cell Tiss Organ Cult DOI 10.1007/s11240-016-1149-4}

In the original publication, the caption to Fig. 3 was incorrect. It should have read as follows:

Fig. 3 Screening of doubled haploids for identification of heterozygotes. SSR marker (RM206) differentiating somatic tissue derived heterozygote from doubled haploids (1 BS6444G; 2, 4-21 representatives of doubled haploids; 3 heterozygote and M 50 bp DNA ladder)

The online version of the original article can be found under doi:10.1007/s11240-016-1149-4.

Sanghamitra Samantaray

smitraray@gmail.com

1 Crop Improvement Division, ICAR-National Rice Research

Institute, Cuttack, Odisha 753 006, India

2 Ravenshaw University, Cuttack, Odisha, India 